\title{
Effect of Different Levels of Tapioca (Manihot esculenta) in Low Fat Probiotic Ice Cream
}

\author{
Gaurav Yadav 1,2*, John David ${ }^{1}$, Sangeeta Shukla ${ }^{1}$, Anu Kumari ${ }^{1}$, \\ Vani Yadav ${ }^{1}$ and Shalini ${ }^{1}$ \\ ${ }^{1}$ Warner College of Dairy Technology, Sam Higginbottom University of Agriculture, \\ Technology and Sciences, Prayagraj-211 007, (U.P), India \\ ${ }^{2}$ Department of Agriculture \& AI, School of Biological Engineering \& Life Sciences, Shobhit \\ Deemed to-be University, Meerut-250110, India \\ *Corresponding author
}

\begin{tabular}{|l|}
\hline Key w o r d s \\
Tapioca, L. casei, \\
Physiochemical, \\
Microbial, Low fat \\
Ice-cream
\end{tabular}

\section{A B S T R A C T}

The research was conducted to determine with the title "Effect of Different Levels of Tapioca (Manihot esculenta) as a Fat Replacer in low Fat Probiotic Ice Cream" to develop suitable technology for the preparation of fat replacer in low fat probiotic ice cream, to access the feasibility of using four levels $(5,10,15$ and 20\%) of tapioca (Maniihot esculenta) with 1,2 and $3 \%$ of $L$. casei. Total 12 treatment combination was used in this study as $\mathrm{T}_{1} \mathrm{~L}_{1}(5 \%$ Tapioca $+1 \%$ L. casei $), \mathrm{T}_{1} \mathrm{~L}_{2}(5 \%$ Tapioca $+2 \%$ L. casei $), \mathrm{T}_{1} \mathrm{~L}_{3}(5 \%$ Tapioca $+3 \%$ L. casei $), \mathrm{T}_{2} \mathrm{~L}_{1}(10 \%$ Tapioca $+1 \%$ L. casei $), \mathrm{T}_{2} \mathrm{~L}_{2}(10 \%$ Tapioca $+2 \%$ L. casei), $\mathrm{T}_{2} \mathrm{~L}_{3}(10 \%$ Tapioca $+3 \%$ L. casei $), \mathrm{T}_{3} \mathrm{~L}_{1}(15 \%$ Tapioca $+1 \%$ L. casei $), \mathrm{T}_{3} \mathrm{~L}_{2}(15 \%$ Tapioca $+2 \%$ L. casei $), \mathrm{T}_{3} \mathrm{~L}_{3}(15 \%$ Tapioca $+3 \%$ L. casei $), \mathrm{T}_{4} \mathrm{~L}_{1}(20 \%$ Tapioca $+1 \%$ L. casei), $\mathrm{T}_{4} \mathrm{~L}_{2}\left(20 \%\right.$ Tapioca $+2 \%$ L. casei) and $\mathrm{T}_{4} \mathrm{~L}_{3}(20 \%$ Tapioca $+3 \%$ L. casei)and all were replicated 4 times. The highest average value of carbohydrate content was obtained in the treatment $\mathrm{T}_{4} \mathrm{~L}_{1} 20 \%$ (31.82). The highest average value of protein and fat content was obtained in the treatment $\mathrm{T}_{1} \mathrm{~L}_{1}$ (4.60 and 2.38). The highest average value of ash content was obtained in the treatment $\mathrm{T}_{1} \mathrm{~L}_{1}(0.98)$. The highest average value of total solid content was obtained in the treatment $\mathrm{T}_{4} \mathrm{~L}_{1}$ (38.82). The highest average value of moisture content was obtained in the treatment $\mathrm{T}_{1} \mathrm{~L}_{2}(67.65)$. The highest average value of acidity content was obtained in the treatment $\mathrm{T}_{4} \mathrm{~L}_{3}(0.32)$. The highest average value of standard plate count was obtained in the treatment $\mathrm{T}_{3} \mathrm{~L}_{3}(5.88)$. The highest average value of yeast and mould score content was obtained in the treatment $\mathrm{T}_{4} \mathrm{~L}_{3}(28.00)$. Coliform count in all the sample was found to be nil.

\section{Introduction}

Frozen Ice-cream may be defined as a delicious sweet dessert which is obtained by suitable blending and processing of cream adding with some other flavoring ingredients or milk products with or without stabilizer or color and with the incorporation of air during 
the freezing process. According to legal definition (PFA) ice cream is a frozen milk product which is obtained from cow or buffalo milk or combination or from cream and other milk product with or without addition of cane sugar, eggs, fruits, fruit juices, preserved fruits, nuts chocolate, edible flavors and permitted food colors. It may contain stabilizer and emulsifiers not exceeding $0.5 \%$ per cent by weight. It should contain not less than $10 \%$ fat, $3.5 \%$ protein and 36\% total solids. This composition is exclusive of air. So, that they are based on the weight of ice cream mix. Ice cream is a whipped product or a cream which contain a great deal of air which effect the density of ice cream ,prevent from being too hard and too cold in the mouth. Ice cream is a high calorie product with the calorie value is about 9.61 11 KJ/g (De, 2006).

Ice cream industry in India has recent origin. It started in nineteen sixties. The icecream/frozen desserts category has witnessed substantial evolution. From the last 10 years ,various traditional flavours has been developed in the category of ice cream, e.g.Vanilla, Chocolate and strawberry along with some other variants like Kesarpista, Mewa Malai, Mango, Elaichi, Tradiotional kulfi etc. The ice-cream market has been through an evolution wherein the category has grown in shape and form right from consumer perception to the products and services being offered. In India Amul leads first position in the market in the ice cream category covering almost one-third of the market, followed by Hindustan Uniliver and Mother Dairy. Baskin Robbins serves more than 25 flavors in their exclusive stores. Vadilal has also the wide range of ice cream in the country serves 150 plus flavors, sold in a variety of more than 300 packs and forms. Ice cream has an evolving market growing at a CAGR (Compound Annual Growth Rate) of over $4 \%$.
Recent surveys results show that there is broad jump in ice cream consumption is in the low-fat and non-fat ice creams categories. As compare to other surveys results showed that low-fat ice cream gaining more popularity than the non-fat ice cream (Anonymous, 2018). This market trend is seen in most developed countries because of consumer concern about the impact of diet on health.

Probiotic foods are those foods which contain live bacteria and yeast which is good for human health and it is used in food in an adequate matrix with sufficient concentration, so that after their ingestion, the postulated effect is obtained, and is beyond that of usual nutrient suppliers (Saxelin and De Vos., 2005).

Dairy products have been considered as a good carrier for probiotics since fermented foods and dairy products have particularly a positive image. A major advantage is that consumers are already familiar with them and many believe that dairy products are healthy, natural products. Dairy ingredients also allow the production of diverse textures and aromas, adding another benefit with the possible range of sensory characteristics. Probiotics help to maintain good balance and composition of intestinal flora increasing the ability to resist pathogens invasion and maintain the host's wellbeing. It also helps in reduction of blood pressure, cholesterol and/or triglycerides levels, reduction of lactose intolerance problems, immune system enhancement, anticarcinogenic activity and improve nutrients utilization. The use of probiotics for preventing and treating illnesses related to gastrointestinal, respiratory and urogenital tracts have been studied. They have been widely used in therapeutic applications as constipation, diarrhea control, bowel syndrome, control of inflammatory processes, prevention of eczema, osteoporosis and food allergy (Aureli et al., 2011; Ranadheera et al., 
2010; Rastall et al., 2000; Vasiljevic and Shah, 2008). The most common probiotic strains used in dairy foods belong to Lactobacillus (L. acidophilus, L. johnsonii, L. gasseri, L. crispatus, L. casei/paracasei, L. rhamnosus, $L$. reuteri, L. plantarum) and Bifidobacterium (Bifidobacterium lactis, $B$. bifidum, $B$. infantis, $B$. breve, $B$. animalis, $B$. adolescentis) genera.

Tapioca (Manihot esculenta), also called manioc, cassava or yuca, it is one of the most important food crops which is being particularly suited to serve as a meal with sufficient nutrition value and able to survive drought or other natural disasters. (Burrell, 2003). Among the starchy staples, cassava is a rich source of carbohydrate production which contain about $40 \%$ higher than rice and $25 \%$ more than maize, so all these parameters gives the result that cassava is the cheapest source of calories for both human nutrition and animal feeding. A typical composition of the cassava root is moisture $(70 \%)$, starch (24\%), fiber (2\%), protein (1\%) and other substances including minerals $(3 \%)$. Tapioca powder contains $13.2 \%$ moisture, $0.6 \%$ Protein, $85 \%$ carbohydrate and $0.2 \%$ fat. Cassava starch can be converted to maltotriose, maltose, and glucose as well as to other modified sugars and organic acids (Tan et al., 1984). Starch from cassava can be used to make fructose syrups (Vuilleumier, 1993) and formulate gelatin capsules (Nduele et al., 1993). The use of cassava as a source of ethanol for fuel is already being exploited extensively. There are several health benefits of tapioca. It help in healthy weight gain, increase circulation and red blood cell count, protect against birth defects, improve digestion, lower cholesterol, prevent diabetes, improve metabolic activities, protect bone mineral density, protect from Alzheimer's disease, maintain heart health, and fluid balance within the body.
With the changing health scenario the demand for calorie reduced foods by consumers is now greater than ever because most adults are overweight. Dietary fat recommendations have motivated declines in consumption of many high fat content foods, including dairy products, because the amount of fat in the diet, having a high correlation with various illnesses, such as obesity and heart disease, which is the top concern for consumers (Sarker and Rahman, 2017). As a consequence, the dairy industry has developed a variety of low-fat or fat-free ice cream products in order to cater to this demand. In the modern era, consumer's choice depends not only on the nutritional benefits of a food product but also visual and sensory qualities of appearance texture and flavor (Shamil and Kilcast, 1992).

Keeping in mind the changing health scenario, public awareness and health benefits of probiotics and tapioca, the objectives of this study was:

To prepare probiotic ice cream with different ratio of tapioca.

To study chemical and microbiological quality of probiotic ice cream.

To estimate cost of production of probiotic ice cream.

\section{Materials and Methods}

The experiments were carried out in the Research Laboratory, Warner College of Dairy Technology, SHUATS, Prayagraj (U.P). Raw milk was procured from experiential Dairy Plant "Aggies" of SHUATS, Prayagraj. Sugar was procured from local market of Prayagraj. Tapioca powder (Flavourlite, ozale e-commerce Pvt. Ltd., Kollam, India) was procured. Stabilizer, emulsifier and flavor (Vanilla) was procured 
from experiential dairy plant "Aggies" of SHUATS, Prayagraj. Probiotic culture was procured from NDRI, Karnal.

The different treatment combination of this study has been listed in Table 1. Total number of treatment combination in this study was 12 . Probiotic ice-cream with different level of Tapioca powder was prepared as per flow diagram shown in Fig. 1.

\section{Chemical analysis}

Moisture content and total solids of low fat probiotic ice-cream were estimated by the procedure as given in AOAC (1990). Soxhlet extraction method as described in AOAC (1984) for estimated fat content of ice-cream. Kjeldhal method as described in AOAC (1984) to determined protein content of icecream. Ash content in ice-cream was estimated as per the procedure given by Ranganna (1986) using muffle furnace. Total carbohydrate in probiotic ice-cream was estimated by difference methods (Bakshi et al., 2019). Acidity in ice-cream was determined by method given in AOAC (1990).

\section{Microbiological analysis}

Standard plate count (SPC) was determined as per the procedure as given by APHA (1992) standard methods for the examination of dairy products. Coliform count was determined as per the procedure given in APHA (1992) standard methods for the examination of dairy products. Yeast and mould count was determined as per the procedure given in APHA (1992).

\section{Cost analysis}

Cost analysis of the product was estimated on the basis of fixed cost and variable cost of assets used in this study.

\section{Statistical analysis}

The data obtained were statistically analyzed by Analysis of Variance (ANOVA) at 5\% level of significance using SPSS version 16 software.

\section{Results and Discussion}

Different samples of probiotic ice-cream in each replication were evaluated for moisture, fat, ash, protein, carbohydrate, acidity, SPC (Standard Plate Count), Yeast and mould, coliform count and cost of the product. The data of all chemical, microbial parameters and cost of production of this study were tabulated in Fig. 2 and Fig. 3, respectively.

\section{Moisture content}

The moisture content of probiotic ice-cream incorporated with different level of tapioca shown in Fig. 2. Moisture content of all the treatment was significantly decreased $(\mathrm{P}<0.05)$ as the level of tapioca increased. Moisture content of product was higher with $5 \%$ of tapioca starch and lower with $20 \%$ tapioca starch with moisture content of 67.65$62.70 \%$ and $60.80-61.76 \%$, respectively.

\section{Fat content}

Fat percentage in tapioca probiotic ice-cream of all treatment was found $2.08-2.38 \%$ as shown in Fig. 2. Fat percent was found significantly different $(\mathrm{p}<0.05)$ of all the treatment of probiotic tapioca ice-cream.

\section{Protein content}

Protein content of developed product was decreased significantly $(\mathrm{p}>0.05)$ with addition of tapioca powder shown in Fig. 2. Protein content of probiotic ice-cream was less due to higher level of tapioca powder and less part of milk present in the product. Protein was found 
between 4.60-4.08 \% in all the developed product.

\section{Ash content}

Ash content of probiotic ice-cream was analyzed and found 0.84-0.98 \% which was not significantly different $(\mathrm{p}>0.05)$ among all the treatment.

\section{Carbohydrate content}

Carbohydrate content of developed probiotic ice-cream was found 24.42-31.82 \% which was significantly different $(\mathrm{p}<0.05)$ in all the treatment. Results also revealed that as the percentage of tapioca increased carbohydrate increased in sample. Increase in carbohydrate content in sample may be due to imparting of carbohydrate present in tapioca.

\section{Total solids}

Total solids percent in probiotic ice-cream was found 32.39-38.82 \% which was significantly different $(\mathrm{p}<0.05)$ in all the treatment. Data regarding total solid content in all the sample (Fig. 2) showed that total solid of ice-cream increased as the tapioca percent increased.

\section{Acidity}

Acidity percentage of all the treatment of probiotic ice-cream was varied between 0.200.32 (\% L.A.) which has shown in Fig. 2. Acidity percentage in all the treatment combination of ice-cream was not significantly different at $5 \%$ level of significant.

Table.1 Treatment combinations of different level of Tapioca powder and probiotic culture

\begin{tabular}{|r|c|c|c|}
\hline S. No. & Treatment Code & Tapioca powder\% & Culture (L. casei.) \% \\
\hline 1. & $\mathrm{T}_{1} \mathrm{~L}_{1}$ & 5 & 1 \\
\hline $\mathbf{2 .}$ & $\mathrm{T}_{1} \mathrm{~L}_{2}$ & 5 & 2 \\
\hline $\mathbf{3 .}$ & $\mathrm{T}_{1} \mathrm{~L}_{3}$ & 5 & 3 \\
\hline $\mathbf{4 .}$ & $\mathrm{T}_{2} \mathrm{~L}_{1}$ & 10 & 1 \\
\hline $\mathbf{5 .}$ & $\mathrm{T}_{2} \mathrm{~L}_{2}$ & 10 & 2 \\
\hline $\mathbf{6 .}$ & $\mathrm{T}_{2} \mathrm{~L}_{3}$ & 10 & 3 \\
\hline $\mathbf{7 .}$ & $\mathrm{T}_{3} \mathrm{~L}_{1}$ & 15 & 1 \\
\hline $\mathbf{8 .}$ & $\mathrm{T}_{3} \mathrm{~L}_{2}$ & 15 & 2 \\
\hline $\mathbf{9 .}$ & $\mathrm{T}_{3} \mathrm{~L}_{3}$ & 15 & 3 \\
\hline $\mathbf{1 0 .}$ & $\mathrm{T}_{4} \mathrm{~L}_{1}$ & 20 & 1 \\
\hline $\mathbf{1 1 .}$ & $\mathrm{T}_{4} \mathrm{~L}_{2}$ & 20 & 2 \\
\hline $\mathbf{1 2 .}$ & $\mathrm{T}_{4} \mathrm{~L}_{3}$ & 20 & 3 \\
\hline
\end{tabular}


Fig.1

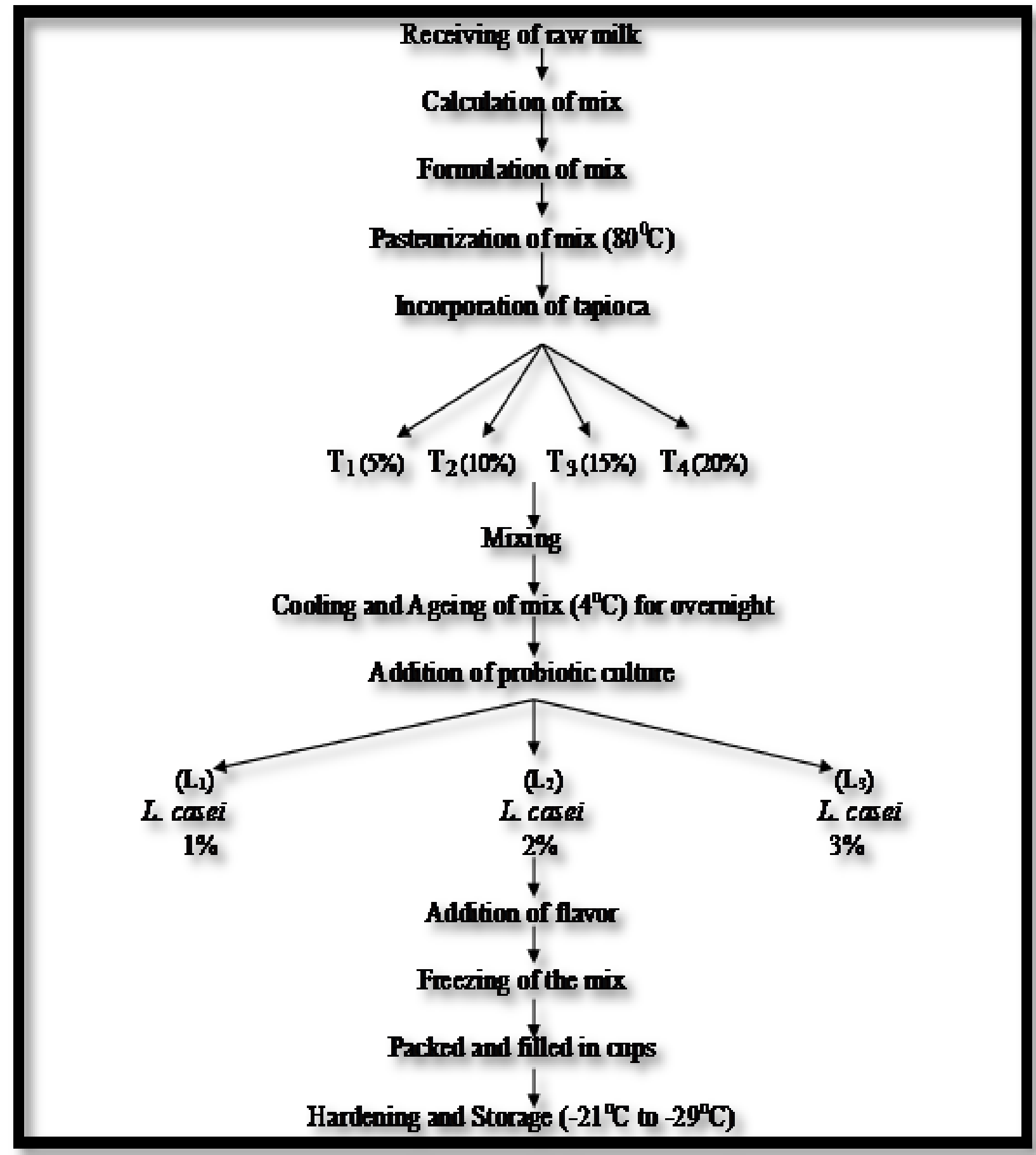


Fig.2 Average of all chemical data obtained in different treatment combination of probiotic tapioca ice-cream

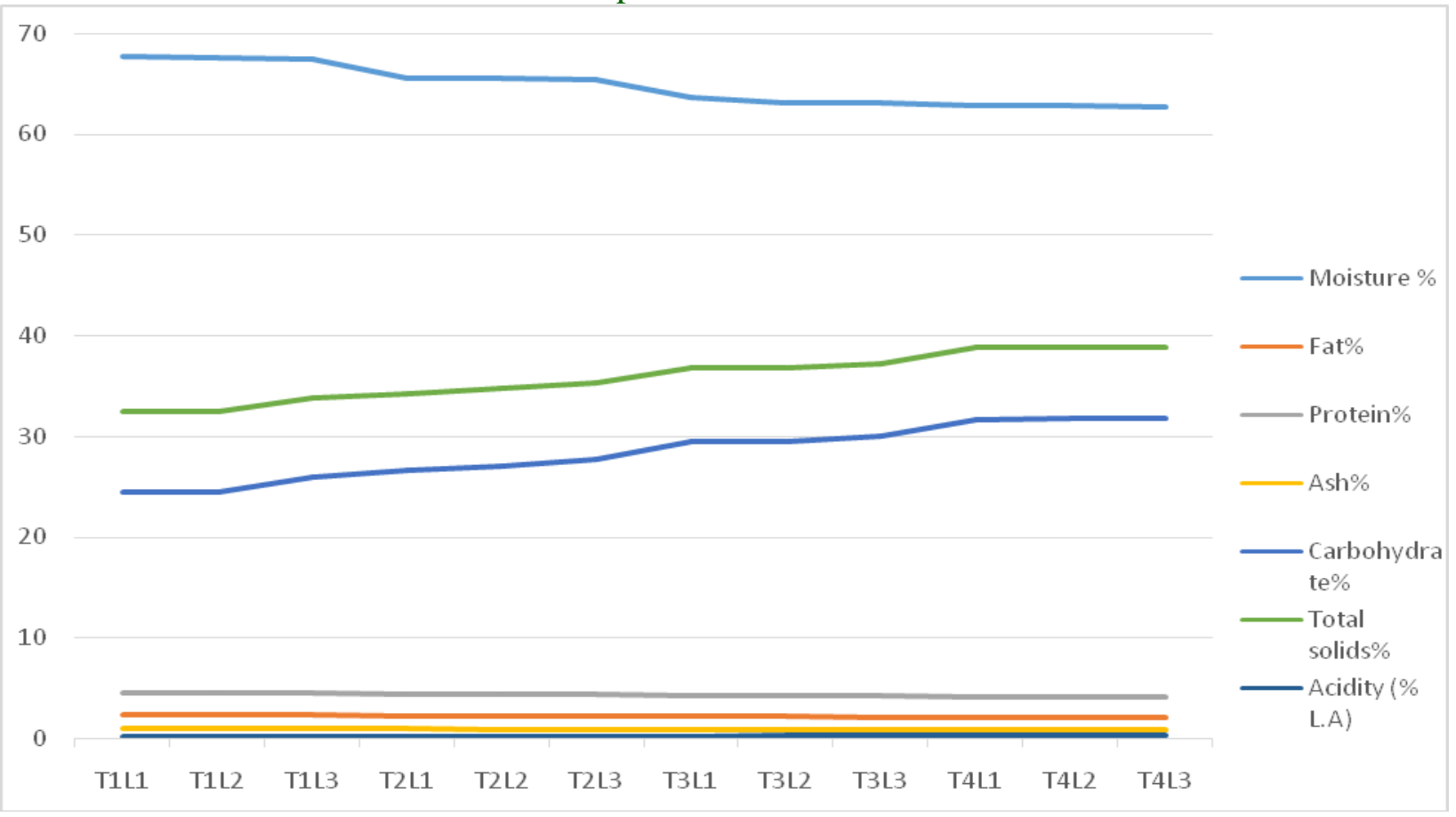

Fig.3 Average of all microbial data and cost of production obtained in different treatment combination of probiotic tapioca ice-cream

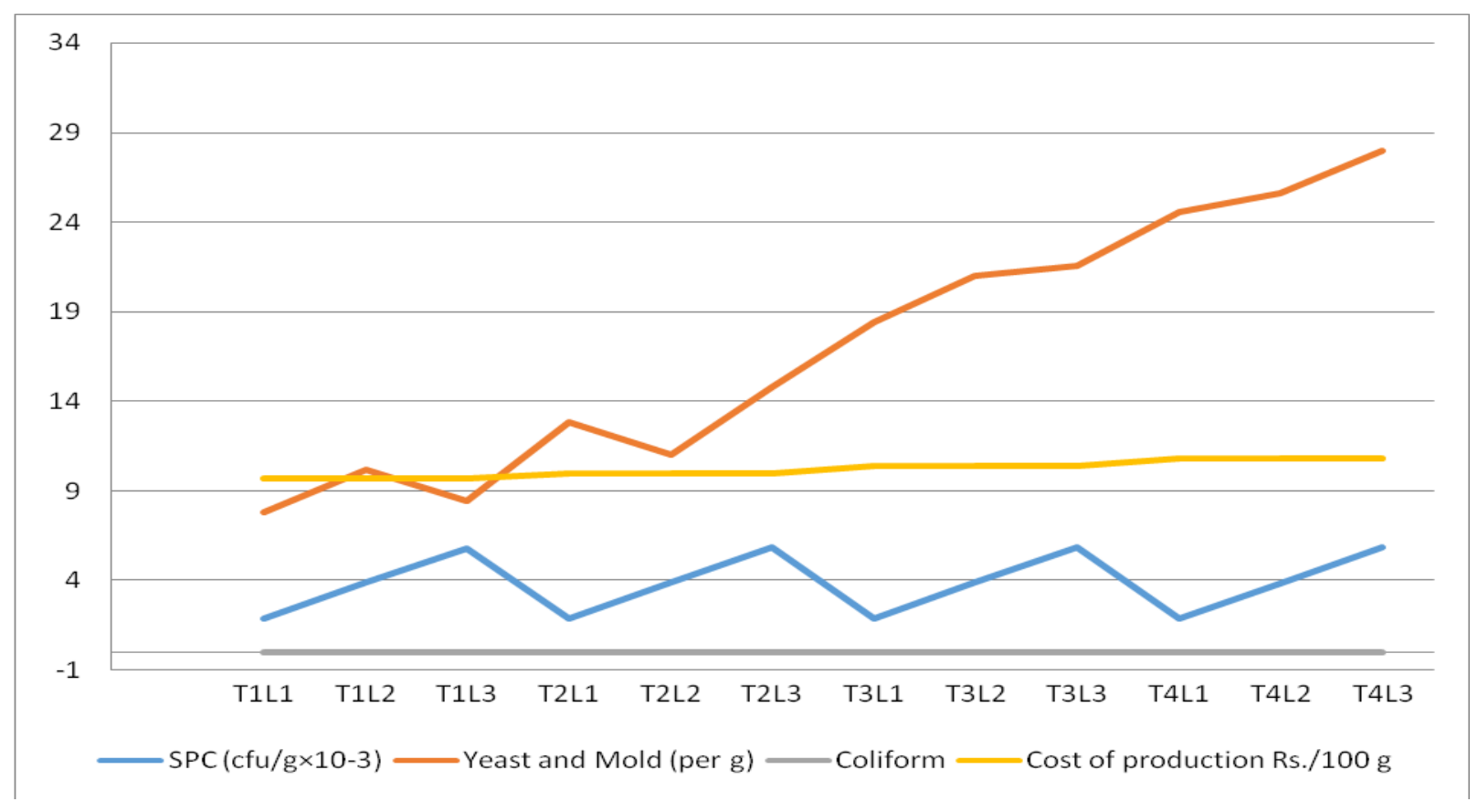




\section{SPC}

Standard plate count in ice-cream sample was analyzed and found that as the level of culture increased number of bacterial cells also increased in the sample (shown in Fig. 3). SPC was found $1.91,3.88$ and $5.81 \mathrm{cfu} / \mathrm{g} \times 10^{-3}$ in treatment with $5 \%$ tapioca powder and 1,2 and $3 \%$ L. casei, respectively. SPC was found $1.89, \quad 3.90$ and $5.86 \mathrm{cfu} / \mathrm{g} \times 10^{-3}$ in treatment with $10 \%$ tapioca powder and 1,2 and $3 \%$ L. casei, respectively. SPC was found $1.89, \quad 3.89$ and $5.88 \mathrm{cfu} / \mathrm{g} \times 10^{-3}$ in treatment with $15 \%$ tapioca powder and 1,2 and $3 \%$ L. casei, respectively. SPC was found $1.88, \quad 3.86$ and $5.87 \mathrm{cfu} / \mathrm{g} \times 10^{-3}$ in treatment with $20 \%$ tapioca powder and 1,2 and $3 \%$ L. casei, respectively.

\section{Yeast and mold}

Yeast and mold in developed low fat ice cream by addition of 5\%,10\%,15\% and $20 \%$ tapioca level was found in the range of 7.8028.00 per g.

\section{Coliform}

Coliform count in all the prepared sample was found nil.

\section{Cost of production}

Cost of production of developed product was calculated and found Rs. 9.7-10.8 for $100 \mathrm{~g}$. It was also observed that as the level of tapioca was increased, cost of production was also increased.

It can be concluding that the low fat probiotic ice cream made by Tapioca was tested by comparing it with the standard of ice cream, it was observed from results that better quality ice cream can be prepared by using Tapioca, Skim milk powder, Milk and Sugar. Tapioca having good source of vitamin $\mathrm{C}$ and Calcium and Phosphorus and probiotics can improve the digestion and boost the immune system in humans. It was observed from results that the prepared ice cream found to be having low fat $\%$ when compared with the standard and acceptance of product was marvelous as per the sensory panel. Among all 12 treatment of probiotic low fat ice cream containing tapioca in the 4 ratio of $\left(\mathrm{T}_{1} \mathrm{~L}_{1}, \mathrm{~T}_{1} \mathrm{~L}_{2}, \mathrm{~T}_{1} \mathrm{~L}_{3}\right) 5 \%$, $\left(\mathrm{T}_{2} \mathrm{~L}_{1}, \mathrm{~T}_{2} \mathrm{~L}_{2}, \mathrm{~T}_{2} \mathrm{~L}_{3}\right) 10 \%,\left(\mathrm{~T}_{3} \mathrm{~L}_{1}, \mathrm{~T}_{3} \mathrm{~L}_{2}, \mathrm{~T}_{3} \mathrm{~L}_{3}\right) 15 \%$, $\left(\mathrm{T}_{4} \mathrm{~L}_{1}, \mathrm{~T}_{4} \mathrm{~L}_{2}, \mathrm{~T}_{4} \mathrm{~L}_{3}\right) 20 \%$ with probiotic culture ratio of $1 \%\left(\mathrm{~T}_{1} \mathrm{~L}_{1}, \mathrm{~T}_{2} \mathrm{~L}_{1}, \mathrm{~T}_{3} \mathrm{~L}_{1}, \mathrm{~T}_{4} \mathrm{~L}_{1}\right), 2 \%$ $\left(\mathrm{T}_{1} \mathrm{~L}_{2}, \mathrm{~T}_{2} \mathrm{~L}_{2}, \mathrm{~T}_{3} \mathrm{~L}_{2}, \mathrm{~T}_{4} \mathrm{~L}_{2}\right), 3 \%\left(\mathrm{~T}_{1} \mathrm{~L}_{3}, \mathrm{~T}_{2} \mathrm{~L}_{3}\right.$, $\mathrm{T}_{3} \mathrm{~L}_{3}, \mathrm{~T}_{4} \mathrm{~L}_{3}$ ).

\section{References}

Anonymous (2018). The state of the global ice cream market. Kerry digests blog, published: Alexis Hosch. Retrieved from $13^{\text {th }}$ August, 2018.

AOAC (1990) Official Methods of Analysis. $15^{\text {th }}$ Edition, Association of Official Analytical Chemist, Washington DC.

AOAC (Association of Analytical Chemist) (1984) Standard Official Methods of Analysis of the Association of Analytical Chemists. $14^{\text {th }}$ Edition, S, W. Williams, Washington DC, $121 \mathrm{p}$.

American Public Health Association (APHA) (1992), Standard Methods for Examination of water.

De, S. (2006). Outlines of dairy technology. Publisher: Oxford University Press, New Delhi, India.

M., Tynkkynen, S., Mattila-Sandholm, T. and De Vos, W.M. (2005). Probiotic and other functional microbes: from markets to mechanism. Current opinion in biotechnology, 16(2): 204211.

Aureli, P., Capurso, L., Castellazzi, A.M., Clerici, M., Giovannini, M., Morelli, L., Poli, A., Pregliasco, F., Salvini, F. and Zuccotti, G.V. (2011). Probiotics and health: an evidence based review. 
Pharmacology Research, 63(5): 366376.

Ranadheera R.D.C.S.; Baines, S.K.; Adams, M.C. (2010). Importance of food in probiotic efficacy. Food Research International, Vol.43, pp.1-7.

Rastall, R. A.; Fuller, R., Gaskins, H. R. (2000). Colonic functional foods. In: Dairy Processing, Gibson G.R., Williams C.M. (eds.), pp. 71-89, CRC Press, Boca Raton

Vasiljevic, T., Shah N P. (2008). Probiotics From Metchnikoff to bioactives. International Dairy Journal, Vol.18, pp.714-728.

Burrell, M. M. Starch: the need for improved quality or quantity--an overview. Journal of Experimental Botany, 2003, vol. 54, no. 382, p. 451-456.

Tan, K.H.; Ferguson, L.B. and Carlton, C. Conversion of cassava starch to biomass, carbohydrates, and acids by Aspergillusniger. Journal of Applied Biochemistry, 1984, vol. 6, no. 1-2, p. 80-90

Vuilleumier, S. Worldwide production of high-fructose syrup and crystalline fructose. American Journal of Clinical Nutrition, 1993, vol. 58, no. 5, p. 733S-736S.

Nduele, M.; Ludwig, A. and van ooteghem, $M$. The use of cassava starch in the formulation of gelatin capsules. Journal de Pharmacie de Belgique, 1993, vol. 48, no. 5, p. 325-334.
Syed Shamil Lisa J.Wyeth David Kilcast, Flavour release and perception in reduced-fat foods Food Quality and Preference: Volume 3, Issue 1, 19911992, Pages 51-60.

Ranganna S. Handbook of analysis and quality control for fruit and vegetable products. 2nd edn, Tata McGraw- Hill Publ, New Delhi, 1986.

Ranganna S. Handbook of Analysis of Quality Control for Fruit and Vegetable Products, Tata McGrawHill Publ. Co., New Delhi, India, 1995.

Bakshi, M. P. S.; Wadhwa, M., 2012. Nutritional evaluation of baby corn husk - A new feed resource for livestock. Indian J. Anim. Sci., 82(12): 1548-1550.

Sarker, M., Rahman M., 2017. Dietary fiber and obesity management, Journal Advances in obesity management, Volume 7 Issue 3.

Cruz-Requena, M., Aguilar-Gonalez C.N., Prado-Barragan L.A., Cunha M.D.G., Correia M.T.D.S., Contreras-Esquivel J.C., Rodriguez-Herrera Raul., 2016 Dietry fiber: An ingredient against obesity., Emirates Journal of Food and Agriculture ., 28(8): 522-530.

Saxelin M., De Vos W.M., 2005, Probiotic and other functional microbes: from markets to mechanisms., Current Opinion in Biotechnology., Vol. 16(2): 204-211.

\section{How to cite this article:}

Gaurav Yadav, John David, Sangeeta Shukla, Anu Kumari, Vani Yadav and Shalini. 2020. Effect of Different Levels of Tapioca (Manihot esculenta) in Low Fat Probiotic Ice Cream. Int.J.Curr.Microbiol.App.Sci. 9(10): 3009-3017. doi: https://doi.org/10.20546/ijcmas.2020.910.362 